\title{
Rural Pastoral Transfers in Classical Pentecostal Churches in Ghana and Pastors Children's Holistic Development
}

\author{
Job Wiredu ${ }^{1}$ \\ ${ }^{1}$ Department of Religious Studies - Kwame Nkrumah University of Science and Technology, Kumasi - Ghana.
}

\begin{abstract}
The transfer of pastors is an age-old phenomenon dating from the early church as recorded in the Bible. This process was conducted in consultation with the Holy Spirit and the leaders of the Church. In the contemporary Church, the same format is used. However, what is lacking is unequal treatment given to pastors who are posted to rural areas that were not evident in the early church. This paper employed the qualitative research approach in studying rural pastoral care in three Classical Pentecostal churches in Ghana. The study findings indicate that children of rural pastors face challenges which affect their holistic development. It recommends pastors and their families should be given fair treatment in the transfer process to ensure the holistic development of their children.
\end{abstract}

Correspondence:

Job Wiredu

Email: jobwiredu74@gmail.com

Publication History

Received 4th June 2021,

Accepted 2nd July 2021,

Published online 9th July 2021.

Keywords: Rural Pastoral Transfer, Equity, Holistic Development

(c) 2021 The Author(s). Published and Maintained by Noyam Publishers.

This is an open access article under the CCBY license (http://creativecommons.org/licenses/by/4.0/).

\section{INTRODUCTION}

Transfers either internal or external are part of the everyday life of a worker. The reshuffling that occurs within the job is what is referred to as internal transfer while the external transfer is what occurs outside the context. ${ }^{1}$ Govindamsy Murugesan describes employee transfer as 'the lateral change triggering the movement of workers from one position or geographical area to another generally without involving a change in duties, responsibilities, skills needed or compensation.' ${ }^{2}$ According to Peter White, transfers are generally instigated either by the company or the employee and may be either temporary or permanent. ${ }^{3}$ Transfers are normally meant to assist employees to gain a broader and wider knowledge and understanding of their organisation. ${ }^{4}$

From antiquity and in most human history, the issue of transfer has been an obvious phenomenon in human life. An Akan proverb says that 'wote faako a wo te wades so, 'meaning, 'if you sit at the same place, you sit on your own thing.' Therefore Classical Pentecostal Pastoral transfer to the author is a move in the right direction. However, pastors working in rural areas face challenges in the development of their children. Constant movements often derail the development of their children and this must be looked at by Church Leadership. This article reflects on this phenomenon from a biblical and contemporary point of view using the data gathered from interviews conducted with various stakeholders of three of the Classical Pentecostal churches in Ghana.

\section{THE BIBLICAL HISTORY OF TRANSFERS AND THE CURRENT SITUATION IN CONTEMPORARY CHURCHES}

From biblical history, pastoral service in the Christian perspective is needed wherever there is human habitation, in either urban or rural areas. There is a biblical affirmation of the above in Acts 11:22 where the church in Jerusalem sent Barnabas to Antioch in Syria to lead a church that had emerged after persecution in Jerusalem. Also Paul the Apostle

\footnotetext{
Peter White, "Pastoral Transfers in Classical Pentecostal Churches in Ghana: Implications for Mission and the Pastoral Family, Ghana," Journal of Religion and Theology, 42 Vol.7 (2017), 123.

Govindamsy Murugesan, Human Resource Management (New Delhi: Laxmi Publications, 2011), 144.

White, "Pastoral Transfers in Classical Pentecostal Churches in Ghana," 123.

White, "Pastoral Transfers in Classical Pentecostal Churches in Ghana," 123.
} 
left Titus whom he had ordained in Crete to superintend a church, to finish his uncompleted assignment (Tit. 1:5). The Book of the Acts of the Apostles indicates that God through the use of persecution scattered the early church because they felt reluctant in moving out of their comfort zones. This, therefore, resulted in the word of God spreading to several places (Acts 8).

However, this cannot be said of the present-day church even though God still calls people and delegates them for missionary purposes. In modern times, the transfer of pastors is done by the leadership of the church for several reasons, some of these reasons have either a positive or negative impact on the personal life of the Pastor, his immediate family, and the church as a whole. ${ }^{5}$

The rural situation in Ghana cannot be compared to situations in the urban areas with regards to the availability of essential amenities such as educational, health and other developmental facilities. In situations of this nature, some church organisations whose churches are situated in both rural and urban centres sometimes, without explanation keep transferring some pastors to rural communities repeatedly for many years together with their children. This is done without considering the plight of these innocent children's future, whereas, in the same organisation, some also continue enjoying urban postings throughout their ministry. There is, therefore, a need for equity to be practiced during transfers so that no pastor's family would be adversely affected in the long run.

\section{Classical Pentecostal Churches in Ghana}

The Classical Pentecostal churches in Ghana are, The Church of Pentecost (CoP), Christ Apostolic Church International (CACI), The Apostolic Church Ghana (TAC-GH) and Assemblies of God Ghana (AG). ${ }^{6}$ Emmanuel Larbi asserted that after revivalist types of figures began emerging on the religious scene during the early part of the twentieth century, some prophetic figures appeared to announce the dawning of a new era, the era of the reign of Christ, demonstrating the power of the gospel. ${ }^{7}$ Notable among these early figures were Prophet Wade Harris from Liberia, who spearheaded the move, Sampson Oppong, John Swatson (a disciple of Harris), and Peter Anim. ${ }^{8}$

Historically, all the three classical Pentecostal churches in Ghana can trace their roots to the work of Peter Anim from 1917. ${ }^{9}$ Larbi posits that the second strand of the renewal movement in the country is the Pentecostal movement. The origin of Evangelical Ghanaian Pentecostalism is largely traced to Peter Anim, and his Faith Tabernacle Church. Out of this organisation emerged three of the classical Pentecostal Churches in Ghana - The Christ Apostolic Church, The Church of Pentecost, and the Apostolic Church. ${ }^{10}$

\section{The Mode of Pastoral Transfer in the three Classical Pentecostal Churches}

Pastoral transfers are described as the procedure with which Pastors are moved from one location to another by the Executive Council and subsequently moving other Pastors from other locations to the vacated locations. In the Classical Pentecostal churches, the transfer of pastors is a mandatory responsibility of the Executive Council. ${ }^{11}$

In the perspective of the CoP, the practice of the regular transfer of Pastors has served as a vital function in the carriage of the mission of the church. The reading of the list of transfers has always been the last thing on the agenda of the General and Extraordinary Council meetings from the time of its inception. The list of transfers is read out by the General Secretary. According to White, reasons for transfers in the $\mathrm{CoP}$ include the transfer of gifts, appointments, discipline, health, and divine orchestration. ${ }^{12} \mathrm{He}$ also posits that some transfers are also politically oriented and that such transfers occur when some pastors (either a subordinate or peer) are deemed to be a threat to the leadership. ${ }^{13}$ Reasons for such politically oriented transfers include an opportunity to compete for an Executive Council position; higher education; greater exposure (i.e. Area Apostle or members of Executive Council); being tagged or perceived to be very vocal or critical. ${ }^{14}$

The immediate past General Secretary of the CoP, Apostle Alfred Koduah in an interview narrated the process they often go through during transfers. ${ }^{15}$ In the process of planning transfers, consistent fasting and prayers are held by

\footnotetext{
White, "Pastoral Transfers in Classical Pentecostal Churches in Ghana," 127.

Emmanuel Kingsley Larbi, Pentecostalism: The Eddies of Ghanaian Christianity (Dansoman-Accra, CPCS, 2017).

Larbi, Pentecostalism, 70.

8 Emmanuel Amankwah, "History of Christ Apostolic Church International," Christ Apostolic Church International. Accessed May 3, 2021. https://christapostolicchurchinternational.wordpress.com/histroy/

9 Larbi, Pentecostalism, 70.

10 Larbi, Pentecostalism, 70.

11 The Church of Pentecost, General Headquarters, Ministerial Handbook, (Pentecost Press Limited,Ghana,2018),49; Christ Apostolic Church International (CAC) Constitution, 2019, $4^{\text {th }}$ Amendment, 25

12 White, "Pastoral Transfers in Classical Pentecostal Churches in Ghana," 127.

13 White, "Pastoral Transfers in Classical Pentecostal Churches in Ghana," 127.

14 Christ Apostolic Church International, Administrative and Financial Policy Manual (Accra: CAC Printing Press, 2005 ), 15.

15 An Interview with Afred Koduah, a former General Secretary of the Church of Pentecost by J .B Dankwah the Pent TV host on transfers of their ministers and other issues of leadership on $5^{\text {th }}$ May, 2021, during the $45^{\text {th }}$ General Council meeting of the Church.
} 
all leaders before decisions are made. He narrated that sometimes when a pastor's name appears in being transferred to a rural station, the council could decide to reverse the decision. The pastor could be sent to an urban station due to certain circumstances. However, despite all efforts to change the transfer due to some certain genuine reasons, will not but still send the person to the rural station community as already done.

In the CACI, a transfer is described as a movement of one officer from one location to the other, or from a department to the other and may or may not involve a change of designation or duties. ${ }^{16}$ The movement from one station to another may not result in increased responsibility, demotion or promotion but rather for efficiency and exigencies of the services. In CACI, the Executive Council effects transfers and these transfers are then subsequently published through circulars or by written notice signed by the General Secretary to the Council.

A senior minister of TAC-GH who served in the Eastern Region narrated that, their mode of transfer was similar to that of CACI. Before the circular letter is released, the ministerial committee ${ }^{17}$ of the church will arrange the transfers for those who are due, then submit it to the general council for approval, and a ministerial letter will be served to the affected ministers informing them of their transfer. ${ }^{18}$

The author is of the view, this is the best as compared to that of CoP system which sometimes is very uncomfortable. It is obvious right at the meeting place some may leave with joy and others with sorrow. A minister shared his experience:

I have already experienced three rural postings for fourteen years, whiles hoping I was due for the fourth transfer but didn't know where to be posted to. As human as I am, due to the previous uncomfortable experience with my family. I nearly fainted when they started calling the names for transfers and the one to relieve me had been mentioned but mine had delayed. ${ }^{19}$

Sometimes, children of these ministers are exposed to this uncomfortable experience. Some narrated; we use to sit by the TV set, especially PENT TV whiles the General Secretary mention names and their respective new stations, during such period, some wept when their parents were posted to rural settings while others jubilated when their parents were posted to urban areas. ${ }^{20}$

White also posited that some pastors who have gone through the same challenges often assumed that their transfers were a result of confrontations they had with leadership. They, therefore, regarded the transfer as a 'punishment'. ${ }^{21}$

To the author, many incidents could trigger a transfer both positive and negative reasons, and no matter which way it goes, the divinely orchestrated aspect mostly outweigh the perceived causes. In the biblical narrative, Joseph son of Jacob had to fulfil the purpose of God in his life through uncomfortable challenges; faced the hatred of his brothers, was sold into slavery, ended up in prison, and later became a Prime Minister. This wouldn't have happened if he had remained peacefully with his family. It is also recorded in Psalm 34:19, that the Lord provides help for the righteous amid adversity. Sometimes, God in His divine purpose allows some challenges to occur, which many a time, ends well as in the case of Joseph recorded in Genesis 50:20. The author who has also served for fourteen years in rural areas as a pastor and is currently serving in an upgraded community can attest to the fact of divinely orchestrated transfers. In his view, he was fulfilling the purpose of God in his life through his rural service.

Pastoral transfers can therefore be viewed as both divinely orchestrated and the prerogative of the Church leadership to help the spread of the Gospel. However, the locus of this article is the effect that these transfers have on the holistic development of the children of pastors posted to rural communities.

\section{METHODOLOGY}

Using a qualitative approach, data was gathered through semi-structured interviews. Due to the nature of the study, AG was not chosen, because, the Church does not embark on ministerial transfers as the remaining three do. The category of 50 respondents included pastors, pastor's wives, children and elders who had previously served or are currently serving in branches of the three churches in rural communities. These communities are located in the Ashanti, Ahafo, Central and Bono Regions of Ghana. Some of the Rural Communities were Ntobroso, Adugyama, Otaakrom, Sreso Timpom, Mpatuam, Sepaase, Dominase, Old Tafo Akim, Begoro, Jumapo, Asummura, Abuom and Pomaakrom.

\section{FINDINGS}

\section{Rural Pastoral Transfers Challenges}

\footnotetext{
16 Christ Apostolic Church International, Administrative and Financial Policy Manual, 15.

17 The Apostolic Church Ghan, Constitution, 3rd Edition, (Review)( May, 2020),29

18 Author's interview with a senior minister in the Apostolic Church Ghana in Eastern Region on their modality of ministers transfer on $28^{\text {th }}$ May 2021

19 Interview with CoP senior Pastor who have served for Thirtenn years in the church and had spent most of his ministry in the rural Areas, on $2^{\text {nd }}$ June, 2021

20 Group discussion with five pastors children who experience most of the rural challenges with their parent when the were posted various transfer which affected their education and social life, on $5^{\text {th }}$ April 2021

21 White, "Pastoral Transfers in Classical Pentecostal Churches in Ghana," 128.
} 
The concurrent transfer of pastors among Classical Pentecostal churches in Ghana has created many challenges and problems for the development of the children involved in the process. The church is generally regarded as a life center, a place for nurturing, liberating, and empowering life in all its completeness. The aim of ministry and pastoral care and counselling, as significant dimensions of ministry, is the fullest likely liberation of individuals in complete relational and societal settings. ${ }^{22}$

In most cases, studies are geared towards pastoral care but not the welfare of the pastor's children. It will be rather abnormal in a situation when much is expected from the pastor by his church organisation, which he cannot deliver due to lack of some human social needs. Rural communities in Ghana are characterized to lack social amenities such as potable drinking water, quality education, quality and affordable health care, and other social amenities. ${ }^{23}$ Children have always been vulnerable. Culturally, and socially children in many ways have been neglected by various institutions including church organisations during decision making. With each succeeding generation, the task of parenting seems more difficult since the world is always evolving.

The challenges faced by the Pastors include getting a quality education for their children. In the event where they are not able to secure appropriate educational facilities for their children, they resort to either placing them in boarding schools or with relations. There are also financial challenges that occur due to the deprived conditions most of the rural folk live in. Most pastors are saddled with the burden of catering for the medical and education bills of their congregants which their income cannot cater for. They often bear these costs to the detriment of their own families. Another challenge is the lack of appropriate accommodation facilities. Most of the respondents of the interviews bemoaned the deplorable state of their accommodation. It must be acknowledged that some of the churches are doing well in providing accommodation for their pastors, however more needs to be done in that area. Most rural pastors also face problems in the efficient discharge of their duties due to a lack of qualified staff to work with. In most areas, the pastor is in charge of every portfolio of the church. All these challenges often pose a lot of stress on the pastor and this affects his ability to properly cater for his children.

Over the past decades, research has revealed that the clergy like any other professional institution has members that experience work-related stress due to several factors. ${ }^{24}$ They are often engaged in managing tasks that put a strain on their resources and energy. ${ }^{25}$ According to Andrew Miles and Rae Jean Proeschold, these stressors have often led to mental and physical distress, which most of the clergy cannot handle effectively. ${ }^{26}$ Most pastors interviewed had psychologically regretted offering themselves to serve in ministry.

\section{The effect of these challenges on the Holistic Development of Pastor's Children.}

The effects of challenges faced by the rural pastor's children have been outlined below. These need to be addressed.

1. Falling Educational Standards of Rural pastors' children: Most of the children interviewed complained of the setbacks they have faced in their education due to the constant movement of their parents which resulted in a constant change of schools. Some of them had to struggle through school with various resits of their subjects and are no longer at par with their peers.

2. Excess Rural Pastoral Financial Constraint, Affect Children's Education: Others also faced financial difficulties since their parents could not pay their fees on time. Others had to quit school at a point and that has adversely affected their development. For the children who were placed in boarding schools, their parents could often not visit them as other parents did due to the distance and its attendant costs. They also could not assess the basic commodities needed to survive in the boarding house due to financial constraints back at home. A senior minister of one of the Classical Pentecostal churches who retired prematurely as a result of rural postings and the incessant financial difficulties narrated that he was not able to cater for his children and this has seriously affected him now that he is on retirement. ${ }^{27}$

3. Pastors Children Spiritual Formation Challenges: Another category of children interviewed were the ones who were placed in other families. They were often maltreated and this led them to engage in various social

\footnotetext{
James W. Thompson, Pastoral ministry according to Paul: A biblical vision, (London Baker Academic, 2006).

23 Rural population (\% of total population) - Ghana, 2018. Accessed January 4, 2021. https://data.worldbank.org/indicator/SP.RUR.TOTL.ZS?locations=GH.

24 Andrew Miles and Rae Jean Proeschold-Bell, "Are Rural Clergy Worse Off?: An Examination of Occupational Conditions and Pastoral Experiences in a Sample of United Methodist Clergy," Sociology of Religion, 73 no 1 (2012): 23-45, https://doi.org/10.1093/socrel/srr025; Lenore M. Johnson, "Models of Clergy Spouse Involvement in Protestant Christian Congregations." Review of Religious Research 54, no. 1 (2012): 19-44.

25 William Kay, Role conflict and British Pentecostal ministers, Journal of Psychology and Religion, 28 no.2 (2000): 119-124; Gary William Kuhne and Joe F. Donaldson. "Balancing Ministry and Management: An Exploratory Study of Pastoral Work Activities." Review of Religious Research 37 , no. 2 (1995): 147-63.

26 Miles and Proeschold-Bell, “Are Rural Clergy Worse Off?”, 199.

27 Researcher's Interview with a retired pastor in a classical Pentecostal Church in Assin Fosu in Central Region, who had retired voluntarily on $17^{\text {th }}$ August, 2020 .
} 
vices to survive. The moral values of the foster parents were often contradictory to that of their parents and they, therefore, picked up various negative habits that have been a hindrance to them to date. Paul states in his first letter to Timothy that, a church leader's household must be above reproach (1Tim 3:2a,4). It is therefore not acceptable for a pastor's ward to be of deviant behaviour. This does not mean that children who stay with their parents are always perfect, yet the obvious possibilities of deviant behaviors are high among those without parental care. What does a minister profit when he positively impacts the lives of others at the expense of his household? The relationship between the pastors and their children is often negatively affected as a result of these challenges. Some of the children felt a sense of neglect and this has contributed to the recalcitrant behaviours they currently portray. Some pastors also feel that they have failed their children because they have not been able to provide for them adequately.

\section{RECOMMENDATIONS}

Most of the respondents interviewed agree to the fact that the challenges discussed above have been age-old concerns and yet there seems to be no system set up by the leadership of the various churches to address the problems to make living in the rural areas favorable for rural pastors. Rural pastoral care will never come to end due to the continued existence of rural folks. Hence it is recommended that classical Pentecostal Churches (unlike the Neo-Pentecostal churches that normally focus on urban areas), which generally have rural missions as part of their focus should strategically plan their activities so that Pastors who are posted to these areas do not feel sidelined. Classical Pentecostal churches need to address this problem to avoid inequality among pastors.

Furthermore, from the study and the experience of the author, it has been observed that members of the committees that formulate various policies in the three classical Pentecostal churches under review often have little or no experience with rural pastoral care. Hence the leadership of the churches are entreated to include rural representatives to effectively contribute to issues to ensure equity and equality.

It is also recommended that the welfare of children of Pastors should be considered during posting. There is a need to establish model schools across the country so that no child is left behind. The pastors would be able to concentrate on their ministry knowing that their wards are well catered for spiritually and physically.

Lastly, special incentives should be provided for rural pastors to make their work easier. Their allowances and salaries should be pegged at a different level so that they can support the rural folk and evangelize effectively. When these are put in place it reduces the anxiety of pastors transferred to rural areas and they can discharge their duties accordingly.

\section{CONCLUSION}

The paper has discussed the challenges faced by children of classical Pentecostal pastors whose parents are transferred to rural communities. Children are the gift from God (Ps 127:3) and Jesus also entreated his followers to treat all children fairly since they occupy a special place in his kingdom (Matt 18:10). This paper is however not against rural pastoral postings but is rather advocating for an all-inclusive decision-making process to ensure that all stakeholders are properly catered for. Therefore the Classical Pentecostal churches must make a conscious effort to see to it there is equity in Rural Pastoral transfers.

\section{ABOUT AUTHOR}

Job Wiredu is a full time minister of The Church of Pentecost, with a BA Theology honours and MA in Theology, Missions and Culture. Currently, he is a PhD Candidate in the Department of Religious Studies - Kwame Nkrumah University of Science and Technology, Kumasi. His research interests are in Pentecostal Rural Pastoral Care in Ghana, Biblical Hermeneutics in Africa Scholarship, and Bible Translation in Africa Context.

\section{BIBLIOGRAPHY}

Amankwah E. "History of Christ Apostolic Church International," Christ Apostolic Church International. Accessed May 3, 2021. https://christapostolicchurchinternational.wordpress.com/histroy/

Christ Apostolic Church International, Administrative and Financial Policy Manual. Accra: CAC Printing Press, 2005. Christ Apostolic Church International (CAC) Constitution, 2019, $4^{\text {th }}$ Amendment. Accra: CAC Printing Press, 2019.

Johnson L. "Models of Clergy Spouse Involvement in Protestant Christian Congregations." Review of Religious Research, 54 no. 1 (2012): 19-44.

Kay W. "Role conflict and British Pentecostal ministers," Journal of Psychology and Religion, 28 no.2 (2000): 119-124. 
Kuhne G.W. and Donaldson J. F. "Balancing Ministry and Management: An Exploratory Study of Pastoral Work

Activities." Review of Religious Research 37, no. 2 (1995): 147-63. https://doi.org/10.2307/3512398

Larbi E.K. Pentecostalism: The Eddies of Ghanaian Christianity. Dansoman-Accra, CPCS, 2017.

Miles A and Proeschold-Bell R. J. "Are Rural Clergy Worse Off?: An Examination of Occupational Conditions and Pastoral Experiences in a Sample of United Methodist Clergy," Sociology of Religion, 73 no 1 (2012): 23-45, https://doi.org/10.1093/socrel/srr025

Murugesan G. Human Resource Management. New Delhi: Laxmi Publications, 2011.

Rural population (\% of total population) - Ghana, 2018. Accessed January 4, 2021. https://data.worldbank.org/indicator/SP.RUR.TOTL.ZS?locations $=\mathrm{GH}$.

The Church of Pentecost, General Headquarters, Ministerial Handbook. Pentecost Press Limited, Ghana, 2018.

Thompson J.W., Pastoral ministry according to Paul: A biblical vision. London Baker Academic, 2006.

White P. "Pastoral Transfers in Classical Pentecostal Churches in Ghana: Implications for Mission and the Pastoral Family, Ghana," Journal of Religion and Theology, 42 no.7 (2017): 123-136. 